\title{
Synthesis and In Vivo Evaluation of Novel PET Radioligands for Imaging the Endothelin-A Receptor
}

\author{
William B. Mathews ${ }^{1}$, Natesan Murugesan ${ }^{2}$, Jinsong $\mathrm{Xia}^{1}$, Ursula Scheffel ${ }^{1}$, John Hilton ${ }^{1}$, Hayden T. Ravert ${ }^{1}$, \\ Robert F. Dannals ${ }^{1}$, and Zsolt Szabo ${ }^{1}$ \\ ${ }^{1}$ Department of Radiology, Johns Hopkins University, Baltimore, Maryland; and ${ }^{2}$ Research and Development, Bristol-Myers Squibb, \\ Princeton, New Jersey
}

The endothelin subtype-A (ETA) receptor is a member of a family of G-protein-coupled receptors that plays a central role in vasoconstriction, cell proliferation, and hormone production. The aim of this study was to synthesize and evaluate in vivo ${ }^{11} \mathrm{C}$ - and ${ }^{18} \mathrm{~F}$-labeled analogs of the potent and selective ETA antagonist $\mathrm{N}$-[[2'-[[(4,5-dimethyl-3-isoxazolyl)amino]sulfonyl]-4-(2-oxazolyl) [1,1'-biphenyl]-2-yl]methyl]-N,3,3-trimethylbutanamide (BMS207940). Methods: Protected precursors and authentic nonradioactive standards were synthesized by reductive amination and subsequent alkylation of protected aldehyde 1. Desmethyl precursor 2 was reacted with ${ }^{11} \mathrm{C}$-methyl iodide followed by deprotection and high-performance liquid chromatography purification to produce ${ }^{11} \mathrm{C}-\left(N-\left[\left[2^{\prime}-[[(4,5-\right.\right.\right.$ dimethyl-3-isoxazolyl)amino] sulfonyl]-4-(2-oxazolyl)[1,1'-biphenyl]-2-yl]methyl]- $N$, 1-methylindolecarboxamide) $\left({ }^{11} \mathrm{C}-\mathrm{BMS}-5 \mathrm{p}\right)$ 3. Nitro precursor 4 was reacted with ${ }^{18} \mathrm{~F}$-fluoride and purified by high-performance liquid chromatography to produce ${ }^{18} \mathrm{~F}-\left(\mathrm{N}-\left[\left[2^{\prime}-[[(4,5-\right.\right.\right.$ dimethyl-3-isoxazolyl)amino]sulfonyl]-4-(2-oxazolyl)[1,1'-biphenyl]-2-yl]methyl]$\mathrm{N}, 4$-fluorobenzamide) ( $\left.{ }^{18} \mathrm{~F}-\mathrm{FBzBMS}\right)$ 5. Biodistribution was determined by injecting male CD-1 mice via the tail vein with either ${ }^{11} \mathrm{C}-\mathrm{BMS}-5 \mathrm{p} 3$ or ${ }^{18} \mathrm{~F}-\mathrm{FBzBMS}$ 5. Specific binding was determined by pretreatment with $1 \mathrm{mg}$ of BMS-207940 per kilogram. PET scanning of a baboon using either ${ }^{11} \mathrm{C}-\mathrm{BMS}-5 \mathrm{p} 3$ or ${ }_{18} \mathrm{~F}-\mathrm{FBzBMS} 5$ was performed at baseline and $40 \mathrm{~min}$ after intravenous administration of $1 \mathrm{mg}$ of BMS-207940 per kilogram. Results: ${ }^{11} \mathrm{C}-\mathrm{BMS}-5 \mathrm{p} 3$ was synthesized with $1.5 \%$ radiochemical yield in $36 \mathrm{~min}$, with an average specific activity of 1,051 $\mathrm{GBq} / \mu \mathrm{mol}(28,400 \mathrm{mCi} / \mu \mathrm{mol} ; n=5)$ at the end of synthesis. ${ }^{18} \mathrm{~F}-\mathrm{FBzBMS} 5$ was synthesized with $0.54 \%$ radiochemical yield in $130 \mathrm{~min}$, with an average specific activity of $12.9 \mathrm{GBq} / \mu \mathrm{mol}$ $(349 \mathrm{mCi} / \mu \mathrm{mol}, n=7)$ at the end of synthesis. In mice, the highest uptake of both radioligands was in the liver, lungs, and heart. Radioactivity in the liver washed out over time, and uptake in the lungs and heart remained relatively stable. Mice pretreated with $1 \mathrm{mg}$ of BMS-207940 per kilogram showed greater than $64 \%$ specific binding in the lungs and kidneys at $60 \mathrm{~min}$. Specific binding in the heart was determined to be $63 \%$ for ${ }^{11} \mathrm{C}-\mathrm{BMS}-5 \mathrm{p} 3$ and $81 \%$ for ${ }^{18} \mathrm{~F}-\mathrm{FBzBMS} 5$. PET studies in a baboon showed

\footnotetext{
Received Feb. 29, 2008; revision accepted May 28, 2008.

For correspondence or reprints contact: William B. Mathews, Department of Radiology, Johns Hopkins University, 720 Rutland Ave., Ross 320, Baltimore, MD 21205.

E-mail: bmathews@jhu.edu

COPYRIGHT @ 2008 by the Society of Nuclear Medicine, Inc.
}

high uptake of both radioligands in the myocardium. Between 35 and $85 \mathrm{~min}$, the heart-to-blood ratio was 4.7 to 1 . Pretreatment with a $1 \mathrm{mg} / \mathrm{kg}$ dose of BMS-207940 showed $85 \%$ specific binding in the myocardium at $85 \mathrm{~min}$ after injection. Conclusion: Both ${ }^{11} \mathrm{C}-\mathrm{BMS}-5 \mathrm{p} 3$ and ${ }^{18} \mathrm{~F}-\mathrm{FBzBMS} 5$ bind selectively to the ETA receptor in vivo. Further development of these radioligands for imaging the ETA receptor in humans is warranted.

Key Words: antagonist; ${ }^{11} \mathrm{C} ;{ }^{18} \mathrm{~F}$; endothelin; PET

J Nucl Med 2008; 49:1529-1536

DOI: 10.2967/jnumed.108.051565

\section{$\mathbf{E}_{1}$} ndothelin receptors are transmembrane proteins that are distributed throughout the body. Their natural ligand, endothelin, was originally described as a potent vasoactive substance (1). It exists in 3 isoforms, designated endothelin1 , endothelin-2, and endothelin-3 (2). A large number of studies have shown that endothelins play many important roles in addition to vasoconstriction, including cell proliferation (3) and hormone production (4). The endothelins act through 2 specific receptors, designated endothelin subtype-A (ETA) and endothelin subtype-B (ETB) $(5,6)$. Extensive preclinical and clinical studies, mainly with ETA receptor antagonists, have shown excellent therapeutic benefits in the treatment of cardiovascular disorders (7-11). Increasing evidence also shows that endothelin promotes tumor growth via its mitogenic and angiogenic effects (1214). The design of potent and selective nonpeptide antagonists of endothelin-1 is vital to defining the role of endothelin in human diseases.

The nonselective agonist peptide endothelin-1 has been labeled with both radioiodine (15) and ${ }^{18} \mathrm{~F}(16)$. The nonselective antagonist L-753,037 was labeled with ${ }^{11} \mathrm{C}$ (17) and used for PET imaging of endothelin receptors in a dog (18). The first selective PET radioligands were the ETA selective antagonist ${ }^{11} \mathrm{C}$-PD156707 and the ETB selective agonist ${ }^{18}$ F-BQ3020 $(19,20)$. The specific activity of ${ }^{11} \mathrm{C}$ PD156707, however, was low, and this radioligand has not been used for in vivo imaging. ETA selective radioligands 
with improved binding characteristics have been synthesized (21-23), but thus far, none has been used for imaging endothelin receptors in humans.

A nonpeptide ETA selective antagonist that has been under development by Bristol-Myers Squibb is $N$-[[2' -[[(4,5-dimethyl3-isoxazolyl)amino]sulfonyl]-4-(2-oxazolyl)[1,1'-biphenyl]-2yl]methyl]-N,3,3-trimethylbutanamide (BMS-207940). This compound has demonstrated high affinity $\left(K_{\mathrm{i}}=10 \mathrm{pM}\right)$ for the ETA receptor in vitro and has 80,000-fold selectivity over ETB (24). This article describes the synthesis and preclinical evaluation of ${ }^{11} \mathrm{C}$ - and ${ }^{18} \mathrm{~F}$-labeled analogs of BMS207940 as radioligands for imaging the ETA receptor with PET (Fig. 1).

\section{MATERIALS AND METHODS}

\section{General}

Protected BMS aldehyde 1 was provided by Bristol-Myers Squibb (24). All chemicals and solvents were of American Chemical Society or high-performance liquid chromatography (HPLC) purity and were used as received. Dimethylformamide was purified by stirring overnight with barium oxide and distilled before use. ${ }^{11} \mathrm{C}$-methyl iodide was produced using a PETtrace MeI Microlab (GE Healthcare). The HPLC system consisted of 2 pumps (model 590EF; Waters), 2 injectors (model 7126; Rheodyne), an in-line ultraviolet detector (254 nm) (model 441; Waters), and a single sodium iodide crystal flow radioactivity detector. All HPLC chromatograms were recorded using Galaxie program software (version 1.9; Varian). Radioactivity measurements were made using a dose calibrator (CRC-15R; Capintec).

All in vivo experimental procedures were undertaken in compliance with U.S. laws governing animal experimentation and were approved by the Johns Hopkins University Animal Care and Use Committee. Male CD-1 mice ( $25 \mathrm{~g}$ ) were obtained from Charles River Laboratories. The male Papio anubis baboon (24 $\mathrm{kg}$ ) was obtained from the Southwest National Primate Research Center.

\section{Synthesis of Protected Desmethyl Precursor to ${ }^{11} \mathrm{C}$-(N-[[2'-[[(4,5-Dimethyl-3-Isoxazolyl)Amino]Sulfonyl]- 4-(2-Oxazolyl)[1,1'-Biphenyl]-2-yl]Methyl]-N, 1-Methylindolecarboxamide) ( $\left.{ }^{11} \mathrm{C}-\mathrm{BMS}-5 \mathrm{p}\right)(2)$}

A 4-mL vial was charged with $10.0 \mathrm{mg}(21.4 \mu \mathrm{mol})$ of protected BMS aldehyde 1. The starting material was dissolved in $400 \mu \mathrm{L}$ of dichloromethane and treated with $3.1 \mu \mathrm{L}$ of acetic acid followed by $8.1 \mu \mathrm{L}$ ( $64 \mu \mathrm{mol}, 3.0$ equivalents [eq.]) of $33 \%$ methylamine in ethanol. The mixture was stirred for $15 \mathrm{~min}$ and then treated with $13.6 \mathrm{mg}(64.2 \mu \mathrm{mol}, 3.0$ eq. $)$ of sodium triacetoxyborohydride. After stirring overnight, the solution was washed with $400 \mu \mathrm{L}$ of water, dried over anhydrous sodium sulfate, and evaporated to give a colorless gum. The intermediate was dissolved in $340 \mu \mathrm{L}$ of dichloromethane and added to a solution of $3.5 \mathrm{mg}$ ( $22 \mu \mathrm{mol}, 1.0$ eq.) of indole-2-carboxylic acid in $60 \mu \mathrm{L}$ of dimethylformamide. The combined solution was treated with $3.9 \mu \mathrm{L}\left(3.2 \mathrm{mg}, 25 \mu \mathrm{mol}, 1.2 \mathrm{eq}\right.$.) of $N, N^{\prime}-$ diisopropylcarbodiimide and stirred at room temperature for $3 \mathrm{~d}$. The reaction mixture was washed with $400 \mu \mathrm{L}$ of water, dried over anhydrous sodium sulfate, and evaporated to give $18.1 \mathrm{mg}$ of a golden solid. The crude product was dissolved in an 80:20 concentration of acetonitrile to water $(500 \mu \mathrm{L})$ and injected $(2 \times$ $250 \mu \mathrm{L})$ onto semipreparative HPLC. The HPLC column $(10 \times$ $250 \mathrm{~mm}$ ) (Alltech C18; Econosil) was eluted with a 70:30 concentration of acetonitrile to water at $10 \mathrm{~mL} / \mathrm{min}$. The product peak (retention time $\left[t_{R}\right]=5 \mathrm{~min}$ ) was collected and evaporated to give $5.4 \mathrm{mg}$ of a white solid. The yield was $40 \%$. ${ }^{1} \mathrm{H}$-nuclear magnetic resonance (NMR) $\left(\mathrm{CDCl}_{3}, 400 \mathrm{MHz}\right) \delta 9.19\left(\mathrm{bs},{ }^{1} \mathrm{H}\right)$, $7.90-8.10(\mathrm{~m}, 3 \mathrm{H}), 7.70(\mathrm{~s}, 2 \mathrm{H}), 7.60\left(\mathrm{dd},{ }^{1} \mathrm{H}, \mathrm{J}=8.0,1.5 \mathrm{~Hz}\right)$, 7.39-7.46 (m, 3H), $7.29(\mathrm{~m}, 1 \mathrm{H}), 7.15(\mathrm{dm}, 1 \mathrm{H}, \mathrm{J}=8.8 \mathrm{~Hz}), 6.82$ (dm, 1H, J = 8.7 Hz), 6.56-6.63 (m, 2H), 4.19-4.26 (m, 3H), 3.36 $(\mathrm{s}, 3 \mathrm{H}), 3.01-3.15(\mathrm{~m}, 2 \mathrm{H}), 2.30(\mathrm{~s}, 3 \mathrm{H}), 1.63(\mathrm{~s}, 6 \mathrm{H})$. Highresolution mass spectroscopy (HRMS) (fast-atom bombardment [FAB]) $m / z$ calculation for $\mathrm{C}_{33} \mathrm{H}_{31} \mathrm{~N}_{5} \mathrm{O}_{6} \mathrm{~S} 625.1995$ found $\mathrm{M}^{+}$ 625.1976.

\section{Radiochemical Synthesis of ${ }^{11} \mathrm{C}-\mathrm{BMS}-5 \mathrm{p}$ (3)}

Precursor $2(0.5 \mathrm{mg}, 0.8 \mu \mathrm{mol})$ was dissolved in $200 \mu \mathrm{L}$ of dimethylformamide and treated with $1.3 \mu \mathrm{L}(1.3 \mu \mathrm{mol}, 1.6$ eq. $)$ of
FIGURE 1. Chemical structures of BMS-207940 and 2 radiolabeled analogs.

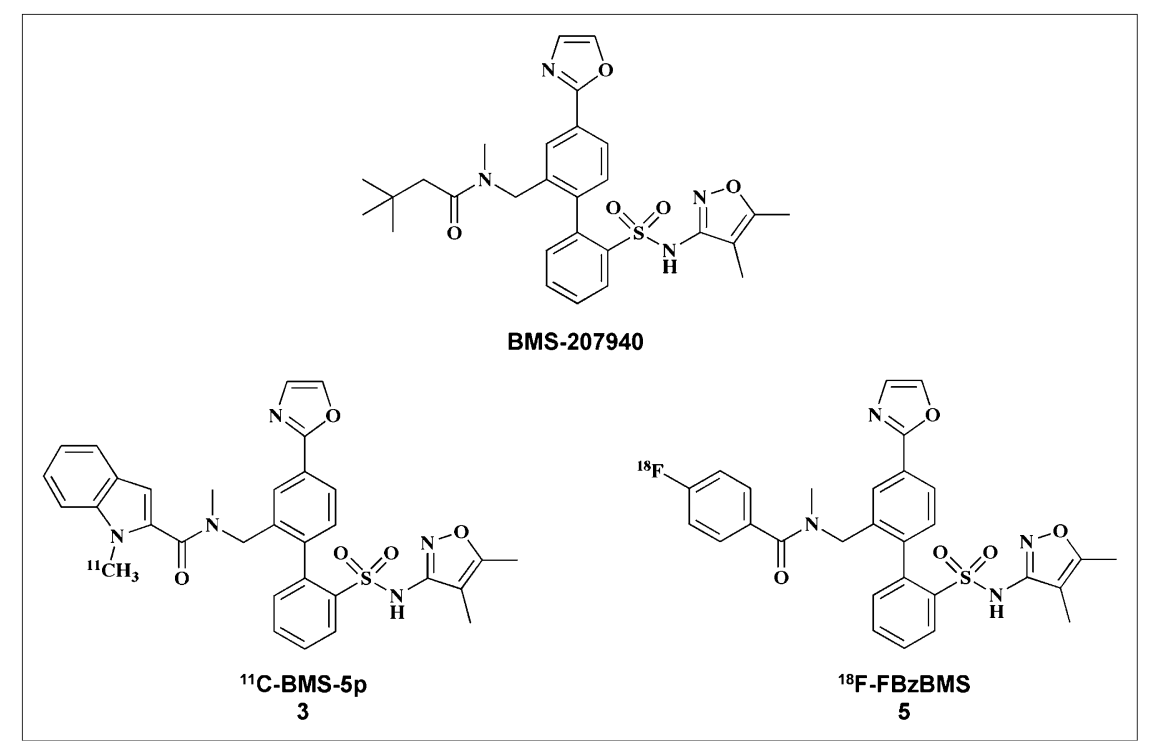


$1 \mathrm{M}$ tetrabutylammonium hydroxide solution in methanol. The precursor solution was cooled to $-42^{\circ} \mathrm{C}$ in a dry ice and acetonitrile bath, and ${ }^{11} \mathrm{C}$-iodomethane was bubbled into the solution until the radioactivity reached a plateau. The vial was removed from the dry ice bath and heated in an $80^{\circ} \mathrm{C}$ water bath for $2 \mathrm{~min}$. The solution was treated with $200 \mu \mathrm{L}$ of $12 \mathrm{~N} \mathrm{HCl}$ and heated in the $80^{\circ} \mathrm{C}$ water bath for $8 \mathrm{~min}$. The reaction mixture was then diluted with a 50:50 concentration of acetonitrile to water $(200 \mu \mathrm{L})$ containing $0.1 \mathrm{M}$ ammonium formate and injected onto semipreparative HPLC. The $10 \times 250 \mathrm{~mm}$ column (Alltech $\mathrm{C} 18$; Econosil) was eluted with a 50:50 concentration of acetonitrile to water containing $0.1 \mathrm{M}$ ammonium formate at a flow rate of 12 $\mathrm{mL} / \mathrm{min}$. The radioactive peak corresponding to ${ }^{11} \mathrm{C}-\mathrm{BMS}-5 \mathrm{p} 3$ $\left(t_{R}=7.2 \mathrm{~min}\right)$ was collected in a rotary evaporator modified for remote addition and removal of solutions. The HPLC solvent was evaporated to dryness at $80^{\circ} \mathrm{C}$ under vacuum. After evaporation, the residue was dissolved in $6.1 \mathrm{~mL}$ of sterile saline and $0.9 \mathrm{~mL}$ of 200-proof ethanol. The solution was remotely passed through a 0.2- $\mu \mathrm{m}$ Millipore Millex GV sterile filter into a sterile, pyrogenfree bottle and diluted with $3.0 \mathrm{~mL}$ of sterile $8.4 \%$ sodium bicarbonate solution. A $100-\mu \mathrm{L}$ aliquot of the final product was injected onto an analytic Alltech C18 Econosil HPLC column $(4.6 \times 250 \mathrm{~mm})$ and eluted with a 50:50 concentration of acetonitrile to water containing $0.1 \mathrm{M}$ ammonium formate at a flow rate of $4 \mathrm{~mL} / \mathrm{min}$. The ultraviolet absorbance of the carrier peak $\left(t_{R}=2.3 \mathrm{~min}\right)$ was measured against that of a calibrated standard to determine specific activity. Chemical identity was confirmed by coelution of the radioactive peak corresponding to ${ }^{11} \mathrm{C}-\mathrm{BMS}-5 \mathrm{p} 3$ with the ultraviolet peak of a standard sample.

\section{Synthesis of Protected Nitro Precursor to ${ }^{18} \mathrm{~F}-\left(\mathrm{N}-\left[\left[2^{\prime}\right.\right.\right.$-[[(4,5-Dimethyl-3-Isoxazolyl)Amino]Sulfonyl]- 4-(2-Oxazolyl)[1,1'-Biphenyl]-2-yl]Methyl]-N,4- Fluorobenzamide) (18F-FBzBMS) (4)}

A 4-mL vial was charged with $50.0 \mathrm{mg}(107 \mu \mathrm{mol})$ of protected BMS aldehyde 1. The starting material was dissolved in $1.1 \mathrm{~mL}$ of dichloromethane and treated with $15.5 \mu \mathrm{L}$ of acetic acid followed by $41 \mu \mathrm{L}$ ( $329 \mu \mathrm{mol}, 3.1$ eq.) of $33 \%$ methylamine in ethanol. The mixture was stirred for $15 \mathrm{~min}$ and then treated with $68.6 \mathrm{mg}$ (324 $\mu \mathrm{mol}, 3.0$ eq.) of sodium triacetoxyborohydride. After the solution was stirred overnight, it was washed with $1.0 \mathrm{~mL}$ of water, dried over anhydrous sodium sulfate, and evaporated to give $76.4 \mathrm{mg}$ of a gold-colored gum. The intermediate was dissolved in $1.1 \mathrm{~mL}$ of dichloromethane and cooled to $0^{\circ} \mathrm{C}$. The solution was treated with $30 \mu \mathrm{L}(215 \mu \mathrm{mol})$ of triethylamine and stirred for $5 \mathrm{~min}$. The solution was then treated with $19.3 \mathrm{mg}$ (104 $\mu \mathrm{mol}, 0.97$ eq.) of 4nitrobenzoyl chloride and allowed to warm to room temperature. The reaction mixture was stirred for $2 \mathrm{~h}$, washed with $1.0 \mathrm{~mL}$ of water, dried over anhydrous sodium sulfate, and evaporated to give $70.3 \mathrm{mg}$ of a white foam. The crude product was dissolved in $1.0 \mathrm{~mL}$ of acetonitrile and injected $(7 \times 150 \mu \mathrm{L})$ onto semipreparative HPLC. The HPLC column $(10 \times 250 \mathrm{~mm})$ (Alltech C18; Econosil) was eluted with a $60: 40$ concentration of acetonitrile to water at $10 \mathrm{~mL} / \mathrm{min}$. The product peak $\left(t_{R}=6 \mathrm{~min}\right)$ was collected and evaporated to give $36.2 \mathrm{mg}$ of a white solid. The yield was $54 \%$. ${ }^{1} \mathrm{H}-\mathrm{NMR}\left(\mathrm{CDCl}_{3}, 400 \mathrm{MHz}\right) \delta 8.30(\mathrm{~d}, 2 \mathrm{H}, \mathrm{J}=$ $8.8 \mathrm{~Hz}), 8.14(\mathrm{~d}, 2 \mathrm{H}, \mathrm{J}=8.8 \mathrm{~Hz}), 7.95-8.07(\mathrm{~m}, 2 \mathrm{H}), 7.78(\mathrm{~d}, 1 \mathrm{H}$, $\mathrm{J}=9.6 \mathrm{~Hz}), 7.44-7.68(\mathrm{~m}, 2 \mathrm{H}), 7.41(\mathrm{~d}, 1 \mathrm{H}, \mathrm{J}=8.0 \mathrm{~Hz}), 7.36(\mathrm{~d}$, $1 \mathrm{H}, \mathrm{J}=7.2 \mathrm{~Hz}), 7.30(\mathrm{~d}, 1 \mathrm{H}, \mathrm{J}=8.0 \mathrm{~Hz}), 7.01(\mathrm{~d}, 1 \mathrm{H}, \mathrm{J}=7.6$ Hz), 4.13-4.82 (m, 4H), 3.27 (s, 3H), 3.09 (s, 3H), 2.31 (s, 3H), $2.29(\mathrm{~s}, 3 \mathrm{H})$. HRMS (FAB) $\mathrm{m} / z$ calculation for $\mathrm{C}_{31} \mathrm{H}_{30} \mathrm{~N}_{5} \mathrm{O}_{8} \mathrm{~S}$ 632.1815 found $(\mathrm{M}+\mathrm{H})^{+} 632.1801$.

\section{Synthesis of FBzBMS (5)}

A 4-mL vial was charged with $10.0 \mathrm{mg}(21.4 \mu \mathrm{mol})$ of protected BMS aldehyde 1. The starting material was dissolved in $400 \mu \mathrm{L}$ of dichloromethane and treated with $2.8 \mu \mathrm{L}$ of acetic acid followed by $7.0 \mu \mathrm{L}$ ( $75 \mu \mathrm{mol}, 3.5$ eq.) of $33 \%$ methylamine in ethanol. The mixture was stirred for $15 \mathrm{~min}$ and then treated with $14.1 \mathrm{mg}$ ( $64 \mu \mathrm{mol}, 3.1 \mathrm{eq}$.) of sodium triacetoxyborohydride. The solution was stirred for $2 \mathrm{~d}$, washed with $400 \mu \mathrm{L}$ of water, dried over anhydrous sodium sulfate, and evaporated to give a colorless gum. The intermediate was dissolved in $400 \mu \mathrm{L}$ of dichloromethane and cooled to $0^{\circ} \mathrm{C}$. The solution was treated with $6.2 \mu \mathrm{L}(44 \mu \mathrm{mol})$ of triethylamine and stirred for $5 \mathrm{~min}$. The solution was then treated with $2.6 \mu \mathrm{L}$ ( $3.4 \mathrm{mg}, 22 \mu \mathrm{mol}, 1.0$ eq.) of 4-fluorobenzoyl chloride and allowed to warm to room temperature. After the reaction mixture was stirred for $1 \mathrm{~h}$, it was washed with $1.0 \mathrm{~mL}$ of water, dried over anhydrous sodium sulfate, and evaporated to give $11.9 \mathrm{mg}$ of a colorless gum.

A $5.0 \mathrm{mg} / \mathrm{mL}$ solution of this material in acetonitrile was treated with $500 \mu \mathrm{L}$ of $6 N$ hydrochloric acid and heated at $80^{\circ} \mathrm{C}$ for $8 \mathrm{~min}$. The crude product was injected onto semipreparative HPLC. The HPLC column $(10 \times 250 \mathrm{~mm})(\mathrm{C} 18$ Luna; Phenomenex) was eluted with a 50:50 concentration of acetonitrile to water $(0.1 \%$ trifluoroacetic acid $)$ at $10 \mathrm{~mL} / \mathrm{min}$. The product peak $\left(\mathrm{t}_{\mathrm{R}}=7 \mathrm{~min}\right)$ was collected and evaporated to give $1.8 \mathrm{mg}$ of a colorless gum. ${ }^{1} \mathrm{H}-\mathrm{NMR}\left(\mathrm{CDCl}_{3}, 400 \mathrm{MHz}\right) \delta 7.90-8.15(\mathrm{~m}, 4 \mathrm{H})$, 7.83 (bs, 1H), 7.27-7.75 (m, 5H), 6.95-7.20 (m, 3H), 4.54 (dd, $2 \mathrm{H}), 3.12$ (s, 3H), 2.27 (s, 3H), 1.85 (s, 3H). HRMS (FAB) $\mathrm{m} / \mathrm{z}$ calculated for $\mathrm{C}_{29} \mathrm{H}_{26} \mathrm{FN}_{4} \mathrm{O}_{5} \mathrm{~S} 561.1608$ found $(\mathrm{M}+\mathrm{H})^{+} 561.1624$.

\section{Radiochemical Synthesis of ${ }^{18} \mathrm{~F}-\mathrm{FBzBMS}(5)$}

${ }^{18}$ F-fluoride was trapped on a quaternary ammonium resin column and eluted into a glassy-carbon reaction vessel with 3.5 mg of potassium carbonate and $15 \mathrm{mg}$ of Kryptofix K222 (Merck) dissolved in an 80:20 concentration of acetonitrile to water $(1.0 \mathrm{~mL})$. The ${ }^{18} \mathrm{~F}$-fluoride was dried by azeotroping with 1.2 $\mathrm{mL}$ of acetonitrile at $110^{\circ} \mathrm{C}$. A solution of precursor $4(4.6 \mathrm{mg}, 7.3$ $\mu \mathrm{mol})$ in $800 \mu \mathrm{L}$ of anhydrous dimethylsulfoxide was added to the reaction vessel and heated at $180^{\circ} \mathrm{C}$ for $30 \mathrm{~min}$. After cooling, the reaction mixture was diluted with $700 \mu \mathrm{L}$ of acetonitrile and $900 \mu \mathrm{L}$ of water. The crude product was injected onto semipreparative HPLC $(10 \times 250 \mathrm{~mm})(\mathrm{C} 18 \mathrm{Luna}$; Phenomenex $)$ and eluted with a 40:60 concentration of acetonitrile to water containing $0.1 \%$ trifluoroacetic acid at $10 \mathrm{~mL} / \mathrm{min}$. The radioactive peak corresponding to ${ }^{18} \mathrm{~F}$-FBzBMS $5\left(t_{\mathrm{R}}=25.3 \mathrm{~min}\right)$ was collected in $60 \mathrm{~mL}$ of water. The dilute product solution was loaded onto a C18 Sep-Pak Plus (Waters). The product was eluted with $1.0 \mathrm{~mL}$ of 200-proof ethanol through a $0.2-\mu \mathrm{m}$ sterile filter (Millex GV; Millipore) into a sterile, pyrogen-free bottle and diluted with $10.0 \mathrm{~mL}$ of sterile saline. A $100-\mu \mathrm{L}$ aliquot of the final product was injected onto an analytic Phenomenex C18 Luna HPLC column $(4.6 \times 150 \mathrm{~mm})$ and eluted with a 40:60 concentration of acetonitrile to water containing $0.1 \%$ trifluoroacetic acid at a flow rate of $4 \mathrm{~mL} / \mathrm{min}$. The ultraviolet absorbance of the carrier peak $\left(t_{R}=8.4 \mathrm{~min}\right)$ was measured against that of a calibrated standard to determine specific activity. Chemical identity was confirmed by coelution of the radioactive peak corresponding to ${ }^{18} \mathrm{~F}$-FBzBMS 5 with the ultraviolet peak of a standard sample. 
TABLE 1

In Vitro Binding Affinity for ETA

\begin{tabular}{lcc}
\hline \multicolumn{1}{c}{ Ligand } & Measured $\mathrm{IC}_{50}(\mathrm{nM})$ & Literature $\mathrm{K}_{\mathrm{i}}(\mathrm{pM})$ \\
\hline BMS-207940 & 4.73 & 10 \\
BMS-5p & 14.26 & 5 \\
FBzBMS & 3.09 & $N A$
\end{tabular}

Seven-point curve ( $n=4$ for each point). Literature $K_{i}$ values are reported in Murugesan et al. (24). NA = not applicable.

\section{In Vitro Binding}

Human kidney cortex and medulla were separated from connective tissue, weighed, and immediately homogenized in an ice-cold hypotonic $20 \mathrm{mM} \mathrm{NaPO}$ and $5 \mathrm{mM}$ ethylenediaminetetraacetic acid solution, $\mathrm{pH} 7.2$, by a mechanical homogenizer. The homogenates were centrifuged $\left(25,000 \mathrm{~g}\right.$ for $20 \mathrm{~min}$ at $\left.4^{\circ} \mathrm{C}\right)$ and the supernatants decanted. The membrane pellets were resuspended by homogenization in assay buffer $(150 \mathrm{mM} \mathrm{NaCl}, 5 \mathrm{mM}$ ethylenediaminetetraacetic acid, $0.1 \mathrm{mM}$ bacitracin, $50 \mathrm{mM} \mathrm{NaPO}_{4}, \mathrm{pH}$ 7.1-7.2). The homogenates were recentrifuged as before and the pellets resuspended by homogenization in the assay buffer at a concentration of $10 \mathrm{~g}$ initial wet weight in $100 \mathrm{~mL}$ of assay buffer. To measure endothelin receptor binding, membrane preparations were incubated with ${ }^{125}$ I-endothelin-1 (School of Pharmacy, University of Mississippi). Competition binding studies were conducted by incubation of $100 \mu \mathrm{L}$ of membrane preparation with 60 pM ${ }^{125}$ I-endothelin-1 in the presence of 7 different concentrations of BMS-207940, BMS-5p 3, or FBzBMS 5 ranging from $10 \mathrm{pM}$ to $10 \mu \mathrm{M}$ ( $n=4$ per point) in a $220-\mu \mathrm{L}$ total assay volume for $4 \mathrm{~h}$ at room temperature. BQ-788 $(100 \mathrm{nM})$ was also added to each membrane preparation to limit binding to the ETB subtype. Free and bound radioligands were separated on glass fiber filters and prewetted with $1 \mathrm{mg}$ of bovine serum albumin per milliliter, using a cell harvester. The bound radioligand retained on the filter circles was assayed with an automated $\gamma$-counter (1282 Compugamma CS; Pharmacia/LKB Nuclear, Inc.). A nonlinear least-squares 4-parameter fit was performed on semilogarithmic dose-response curves with an equation that included the upper limit, lower limit (background, nondisplaceable binding), $50 \%$ inhibitory concentration values $\left(\mathrm{IC}_{50}\right)$, and Hill's coefficient $(25,26)$.

\section{Biodistribution in Mice}

Healthy, nonfasted male CD-1 mice were injected via the tail vein with $11.3 \mathrm{MBq}\left(306 \mu \mathrm{Ci}, 0.2 \mu \mathrm{g} / \mathrm{kg}\right.$ ) of ${ }^{11} \mathrm{C}-\mathrm{BMS}-5 \mathrm{p} 3$ or 2.7
MBq $(72 \mu \mathrm{Ci}, 2.55 \mu \mathrm{g} / \mathrm{kg})$ of ${ }^{18} \mathrm{~F}-\mathrm{FBzBMS}$ 5. Three mice each were sacrificed by cervical dislocation at $5,15,30,60$, and $90 \mathrm{~min}$ after injection. The liver, lungs, heart, kidneys, and whole brain were quickly removed and put on ice. The ${ }^{18} \mathrm{~F}-\mathrm{FBzBMS} 5$ study included a 120-min time point and a sample of femur taken at 60 and $120 \mathrm{~min}$. A $0.1-\mathrm{mL}$ sample of blood was also collected at each time point. The organs were weighed and tissue radioactivity was measured with an automated $\gamma$-counter. The percentage injected dose per gram of tissue $(\% \mathrm{ID} / \mathrm{g})$ was calculated by comparison with samples of a standard dilution of the initial dose. All measurements were corrected for decay. To demonstrate specific binding to the ETA receptor, 3 mice in each study were given an intravenous $1 \mathrm{mg} / \mathrm{kg}$ dose of BMS-207940 $5 \mathrm{~min}$ before administration of the radiotracer. The blocked mice were sacrificed $60 \mathrm{~min}$ after injection of the radioligand. All tissue samples were handled as described above.

\section{PET Imaging in Baboon}

Anesthesia was induced in a male baboon (Papio anubis, $24 \mathrm{~kg}$ ) with an intramuscular injection of a $5-25 \mathrm{mg} / \mathrm{kg}$ dose of ketamine and was maintained with intravenous infusion of propofol at a rate of $100-200 \mu \mathrm{g} / \mathrm{kg} / \mathrm{min}$. The animal was intubated, and heart rate, blood pressure, and oxygen saturation were continuously monitored. ${ }^{11} \mathrm{C}-\mathrm{BMS}-5 \mathrm{p} 3$ was injected intravenously in an average dose of $292 \pm 25 \mathrm{MBq}(7.88 \pm 0.68 \mathrm{mCi}, 0.22 \pm 0.01 \mu \mathrm{g}) .{ }^{18} \mathrm{~F}-$ FBzBMS 5 was injected intravenously in an average dose of $158 \pm 12 \mathrm{MBq}(4.28 \pm 0.33 \mathrm{mCi}, 9.82 \pm 3.15 \mu \mathrm{g})$. Displaceable binding was measured by intravenous administration of a $1 \mathrm{mg} / \mathrm{kg}$ dose of BMS-207940 at the end of the baseline study. An inhibition PET study was then performed after a 40-min uptake period. For both studies, PET images were acquired over $90 \mathrm{~min}$ according to the following protocol: Ten 1-min images, ten 5-min images, and three 10-min images. The baboon was not moved between studies.

\section{PET Image Processing}

The PET images were reconstructed by ordered-subset expectation maximization. To obtain time-activity curves, regions of interest were marked out around the myocardium and lungs. All curves were corrected for isotope decay and injected dose and were expressed in $\mathrm{Bq} / \mathrm{mL} / \mathrm{MBq}(\mathrm{nCi} / \mathrm{mL}$ tissue $/ \mathrm{mCi}$ ) injected dose.

\section{Analysis of Plasma Metabolites in Mice}

Four healthy, nonfasted male CD-1 mice were given an intraperitoneal injection of either $37 \mathrm{MBq}(1 \mathrm{mCi})$ of ${ }^{11} \mathrm{C}-\mathrm{BMS}-5 \mathrm{p} 3$ or $7.4 \mathrm{MBq}(0.2 \mathrm{mCi})$ of ${ }^{18} \mathrm{~F}-\mathrm{FBzBMS}$ 5. The mice were sacrificed by decapitation at $5,10,20$, and $40 \mathrm{~min}$ after injection. Plasma

TABLE 2

Mouse Biodistribution Data for ${ }^{11} \mathrm{C}-\mathrm{BMS}-5 \mathrm{p} 3$ (\%ID/g)

\begin{tabular}{|c|c|c|c|c|c|}
\hline \multirow[b]{2}{*}{ Organ } & \multicolumn{5}{|c|}{ Biodistribution times (min) } \\
\hline & 5 & 15 & 30 & 60 & 90 \\
\hline Liver & $43.46 \pm 4.99$ & $38.70 \pm 3.99$ & $25.89 \pm 1.84$ & $20.72 \pm 0.37$ & $13.43 \pm 0.74$ \\
\hline Lungs & $9.22 \pm 1.40$ & $7.58 \pm 0.68$ & $7.50 \pm 0.54$ & $6.97 \pm 1.59$ & $7.16 \pm 0.82$ \\
\hline Heart & $5.07 \pm 0.27$ & $3.24 \pm 0.15$ & $2.82 \pm 0.29$ & $2.73 \pm 0.34$ & $3.42 \pm 0.51$ \\
\hline Kidneys & $9.15 \pm 1.55$ & $4.78 \pm 0.20$ & $3.93 \pm 0.18$ & $2.81 \pm 0.40$ & $2.59 \pm 0.37$ \\
\hline Blood & $12.91 \pm 0.38$ & $5.78 \pm 1.76$ & $5.17 \pm 3.41$ & $1.53 \pm 0.40$ & $1.12 \pm 0.20$ \\
\hline Brain & $0.38 \pm 0.06$ & $0.24 \pm 0.03$ & $0.11 \pm 0.01$ & $0.07 \pm 0.01$ & $0.09 \pm 0.01$ \\
\hline
\end{tabular}


TABLE 3

Mouse Biodistribution Data for ${ }^{18} \mathrm{~F}-\mathrm{FBzBMS} 5$ (\%ID/g)

\begin{tabular}{lrrrrrr}
\hline & \multicolumn{5}{c}{ Biodistribution times $(\mathrm{min})$} \\
\cline { 2 - 6 } Organ & \multicolumn{1}{c}{5} & \multicolumn{1}{c}{15} & \multicolumn{1}{c}{30} & \multicolumn{1}{c}{60} & 90 \\
\hline Liver & $62.70 \pm 1.26$ & $64.66 \pm 6.22$ & $44.66 \pm 8.14$ & $37.71 \pm 6.67$ & $23.37 \pm 2.67$ & $12.95 \pm 2.36$ \\
Lungs & $3.76 \pm 0.29$ & $5.14 \pm 0.99$ & $5.80 \pm 1.01$ & $6.04 \pm 0.73$ & $5.89 \pm 0.98$ & $5.09 \pm 2.16$ \\
Heart & $2.37 \pm 0.11$ & $2.70 \pm 0.14$ & $3.07 \pm 0.08$ & $3.08 \pm 0.34$ & $3.06 \pm 0.02$ & $3.08 \pm 0.68$ \\
Kidneys & $8.42 \pm 1.39$ & $7.09 \pm 0.27$ & $4.67 \pm 1.00$ & $3.75 \pm 0.38$ & $3.02 \pm 0.12$ & $1.83 \pm 0.62$ \\
Bone & & & & $1.79 \pm 0.16$ & $1.72 \pm 0.38$ \\
Blood & $3.44 \pm 0.27$ & $2.30 \pm 0.44$ & $1.85 \pm 0.34$ & $1.00 \pm 0.19$ & $0.61 \pm 0.05$ & $0.40 \pm 0.12$ \\
Brain & $0.11 \pm 0.00$ & $0.11 \pm 0.01$ & $0.07 \pm 0.02$ & $0.05 \pm 0.01$ & $0.04 \pm 0.00$ & $0.03 \pm 0.01$ \\
& & & & &
\end{tabular}

Data are means \pm SDs $(n=3)$.

from heparinized blood was diluted to $4 \mathrm{~mL}$ with $8 \mathrm{M}$ urea acidified with $50 \mathrm{mg}$ of citric acid. The diluted solutions were analyzed by HPLC using the column-switching method (27). A Strata (Phenomenex) capture column was used with a Synergi Max-RP (Phenomenex) $4.6 \times 250 \mathrm{~mm}$ analytic column running at $2 \mathrm{~mL} / \mathrm{min}$. The HPLC eluent used was $65 \%$ acetonitrile to $35 \%$ water containing $0.1 \%$ trifluoroacetic acid for ${ }^{11} \mathrm{C}-\mathrm{BMS}-5 \mathrm{p} 3$ and $55 \%$ acetonitrile to $45 \%$ water containing $0.1 \%$ trifluoroacetic acid for ${ }^{18} \mathrm{~F}-\mathrm{FBzBMS} \mathbf{5}$.

\section{Analysis of Plasma Metabolites in Baboon}

Samples (1-2 mL) of heparinized whole blood were taken at 5, $15,30,60$, and $90 \mathrm{~min}$ and centrifuged. The plasma samples were treated and analyzed as described above.

\section{RESULTS}

\section{Chemistry and Radiolabeling}

HPLC analysis of the ${ }^{11} \mathrm{C}-\mathrm{BMS}-5 \mathrm{p} 3$ reaction mixture showed a significant amount of protected ${ }^{11} \mathrm{C}$-methyl intermediate even after acid hydrolysis at $80^{\circ} \mathrm{C}$. Nevertheless, ${ }^{11} \mathrm{C}-\mathrm{BMS}-5 \mathrm{p} 3$ was synthesized in $36 \mathrm{~min}$ with an average radiochemical yield of $1.5 \% \pm 0.4 \%$ (uncorrected for decay). The specific activity of ${ }^{11} \mathrm{C}-\mathrm{BMS}-5 \mathrm{p} 3$ was $1,051 \mathrm{GBq} / \mu \mathrm{mol}(28,400 \mathrm{mCi} / \mu \mathrm{mol}, n=5)$ at the end of synthesis. HPLC analysis of the ${ }^{18} \mathrm{~F}-\mathrm{FBzBMS} 5$ reaction mixture showed no protected ${ }^{18} \mathrm{~F}$-fluorobenzoyl intermedi-

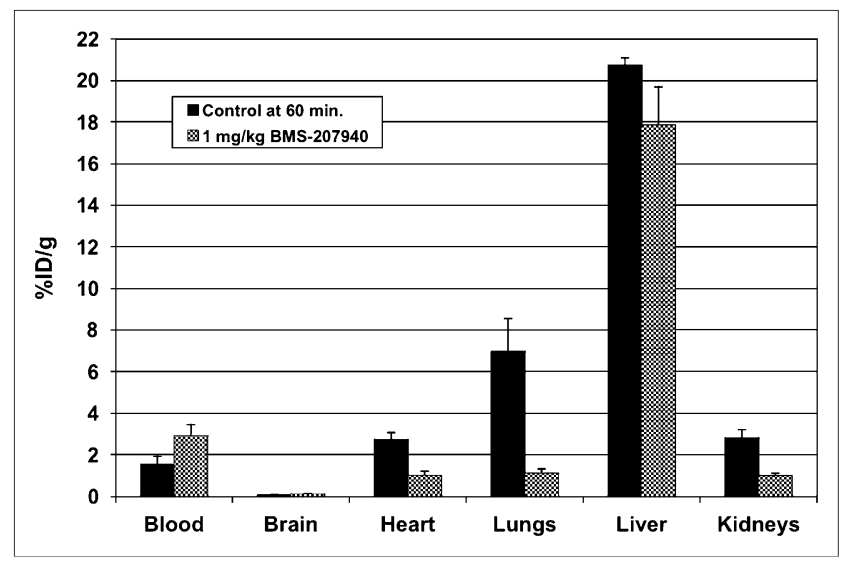

FIGURE 2. Inhibition of ${ }^{11} \mathrm{C}-\mathrm{BMS}-5 \mathrm{p} 3$ uptake in mice. ate after heating at $180^{\circ} \mathrm{C} .{ }^{18} \mathrm{~F}-\mathrm{FBzBMS} 5$ was synthesized in $130 \mathrm{~min}$ with an average radiochemical yield of $0.54 \% \pm$ $0.44 \%$ (uncorrected for decay). The specific activity of ${ }^{18} \mathrm{~F}-$ FBzBMS 5 was $12.9 \mathrm{GBq} / \mu \mathrm{mol}(349 \mathrm{mCi} / \mu \mathrm{mol}, n=7)$ at the end of synthesis. The radiochemical purity of both radioligands was greater than $99 \%$ as determined by analytic HPLC.

\section{In Vitro Binding}

Relative in vitro binding affinity for ETA was determined using homogenized human kidney tissue. Experimental $\mathrm{IC}_{50}$ values are presented with literature $\mathrm{K}_{\mathrm{i}}$ values in Table 1 .

\section{Biodistribution in Mice}

The kinetic distribution of ${ }^{11} \mathrm{C}-\mathrm{BMS}-5 \mathrm{p} \quad \mathbf{3}$ and ${ }^{18} \mathrm{~F}$ FBzBMS 5 was determined in healthy male CD-1 mice after intravenous injection of the radiotracer. Tables 2 and 3 show the decay-corrected \% ID/g data for all organs and time points. For both radioligands, the highest uptake was in the liver, lungs, and heart. Radioactivity in the liver washed out over time, and uptake in the lungs and heart remained relatively stable.

${ }^{18} \mathrm{~F}-\mathrm{FBzBMS} 5$ showed higher liver uptake than did ${ }^{11} \mathrm{C}$ BMS-5p 3, even at later time points. No significant uptake of either tracer in the brain was demonstrated. Radioactiv-

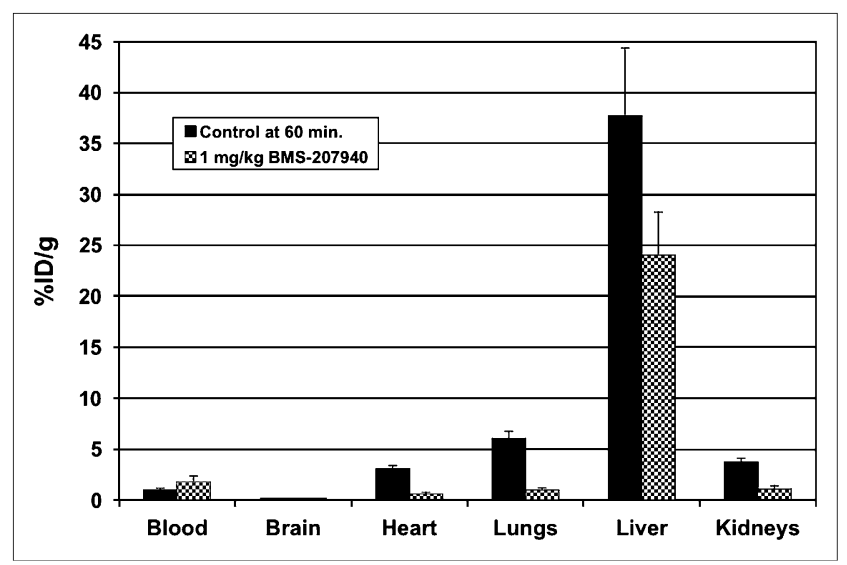

FIGURE 3. Inhibition of ${ }^{18} \mathrm{~F}-\mathrm{FBzBMS} 5$ uptake in mice. 

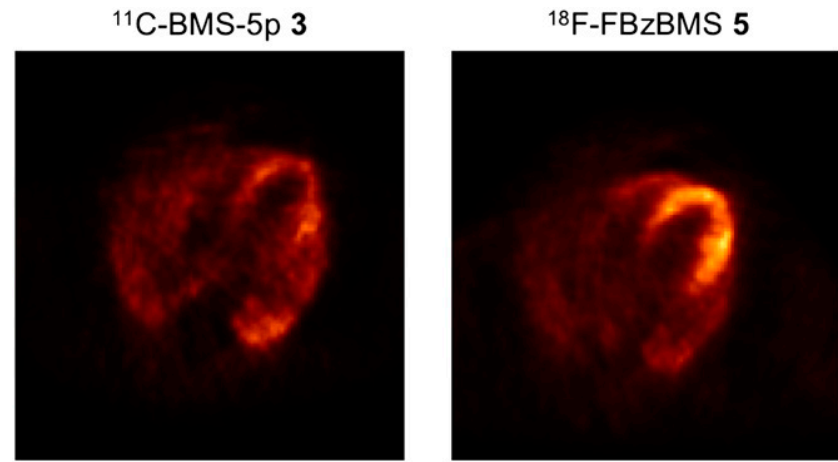

FIGURE 4. Baseline in vivo PET images of baboon heart at 40-90 min after injection.

ity in the bone after injection of ${ }^{18} \mathrm{~F}-\mathrm{FBzBMS} 5$ showed less than $2 \% \mathrm{ID} / \mathrm{g}$ uptake.

Mice pretreated with a $1 \mathrm{mg} / \mathrm{kg}$ dose of BMS-207940 showed greater than $64 \%$ specific binding at $60 \mathrm{~min}$ in the lungs and kidneys. This was true for both radioligands, and these results are shown in Figures 2 and 3. Specific binding in the heart was determined to be $63 \%$ for ${ }^{11} \mathrm{C}-\mathrm{BMS}-5 \mathrm{p} 3$ and $81 \%$ for ${ }^{18} \mathrm{~F}-\mathrm{FBzBMS} \mathbf{5}$. Assays for metabolites in mouse plasma showed $14 \%$ of ${ }^{11} \mathrm{C}-\mathrm{BMS}-5 \mathrm{p} 3$ metabolized at $25 \mathrm{~min}$. This amount compares with only $8.5 \%$ of ${ }^{18} \mathrm{~F}-$ FBzBMS 5 metabolized at $40 \mathrm{~min}$.

\section{PET Imaging in Baboon}

As shown in Figure 4, in vivo PET images of a baboon showed high uptake of both radioligands in the myocardium and less uptake in the lungs. Between 35 and 85 min, the heart-to-blood ratio was 4.7 to 1 . Time-activity curves derived from the baseline and inhibition PET studies are shown in Figure 5. Pretreatment with a $1 \mathrm{mg} / \mathrm{kg}$ dose of BMS-207940 showed $85 \%$ specific binding in the myocardium at $85 \mathrm{~min}$ after injection. Assays for metabolites in baboon plasma showed $36 \%$ of ${ }^{11} \mathrm{C}-\mathrm{BMS}-5 \mathrm{p} 3$ and $37 \%$ of ${ }^{18} \mathrm{~F}-\mathrm{FBzBMS} 5$ metabolized at $90 \mathrm{~min}$.

\section{DISCUSSION}

Although no fewer than 8 endothelin ligands had been radiolabeled for PET before this work, none, to our knowledge, has been used to image endothelin receptors in humans (28). The first radiotracers for endothelin either were nonselective (15-18) or were synthesized at relatively low specific activity (19). Selective radioligands with improved binding characteristics have since been synthesized (21-23) but in some cases showed unfavorable metabolism in vivo (22). The target organ is the heart. The density of the ETA receptor in control heart membranes is approximately $35 \mathrm{fmol} / \mathrm{mg}$ and is upregulated more than $100 \%$ in dilated cardiomyopathy (29).

Precursors $\mathbf{2}$ and $\mathbf{4}$ as well as nonradioactive standards of BMS-5p 3 and FBzBMS 5 were synthesized from protected BMS aldehyde 1 following general procedures described by Murugesan et al. (24). The syntheses are outlined in Scheme 1. BMS-5p 3 is somewhat more lipophilic than FBzBMS 5, as evidenced by both calculated $\log P$ values and reverse-phase HPLC conditions. Relative in vitro binding affinity was determined using a homogenized mixture of cortex and medulla obtained from human kidney specimens. Although the measured $\mathrm{IC}_{50}$ values do not match the known $\mathrm{K}_{\mathrm{i}} \mathrm{s}$ reported in the literature (24), all 3 ligands tested demonstrated similar in vitro affinity for the ETA receptor. The difference between measured affinities and the literature $\mathrm{K}_{\mathrm{i}}$ values can be attributed to the different substrates used by the 2 assays. The literature $K_{i}$ values were obtained from Chinese hamster ovary cells engineered to express the human ETA receptor.

${ }^{11} \mathrm{C}-\mathrm{BMS}-5 \mathrm{p} 3$ was synthesized by ${ }^{11} \mathrm{C}$ methylation of protected precursor 2 . The synthesis is shown in Scheme 2. Deprotection of the ${ }^{11} \mathrm{C}$-methyl intermediate by acid hydrolysis did not reach completion after it had been heated at
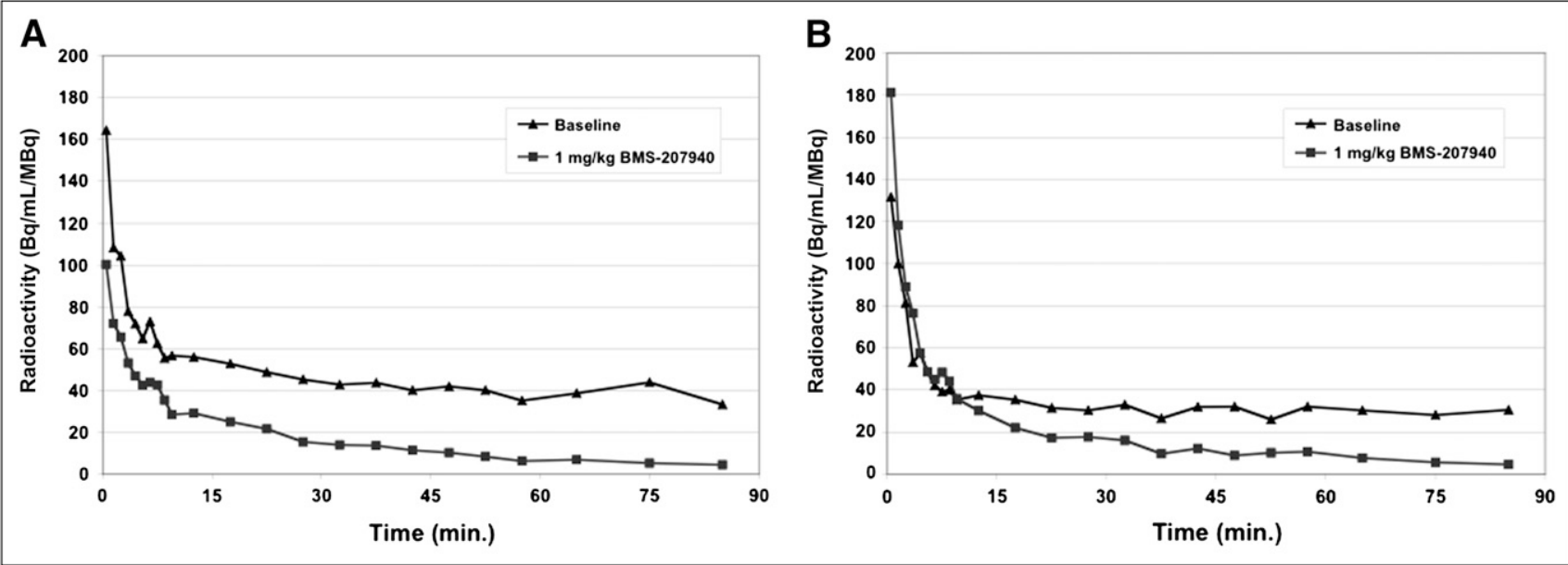

FIGURE 5. Time-activity curves for ${ }^{11} \mathrm{C}-\mathrm{BMS}-5 \mathrm{p} 3(\mathrm{~A})$ and ${ }^{18} \mathrm{~F}-\mathrm{FBzBMS} 5(\mathrm{~B})$ in myocardium. 


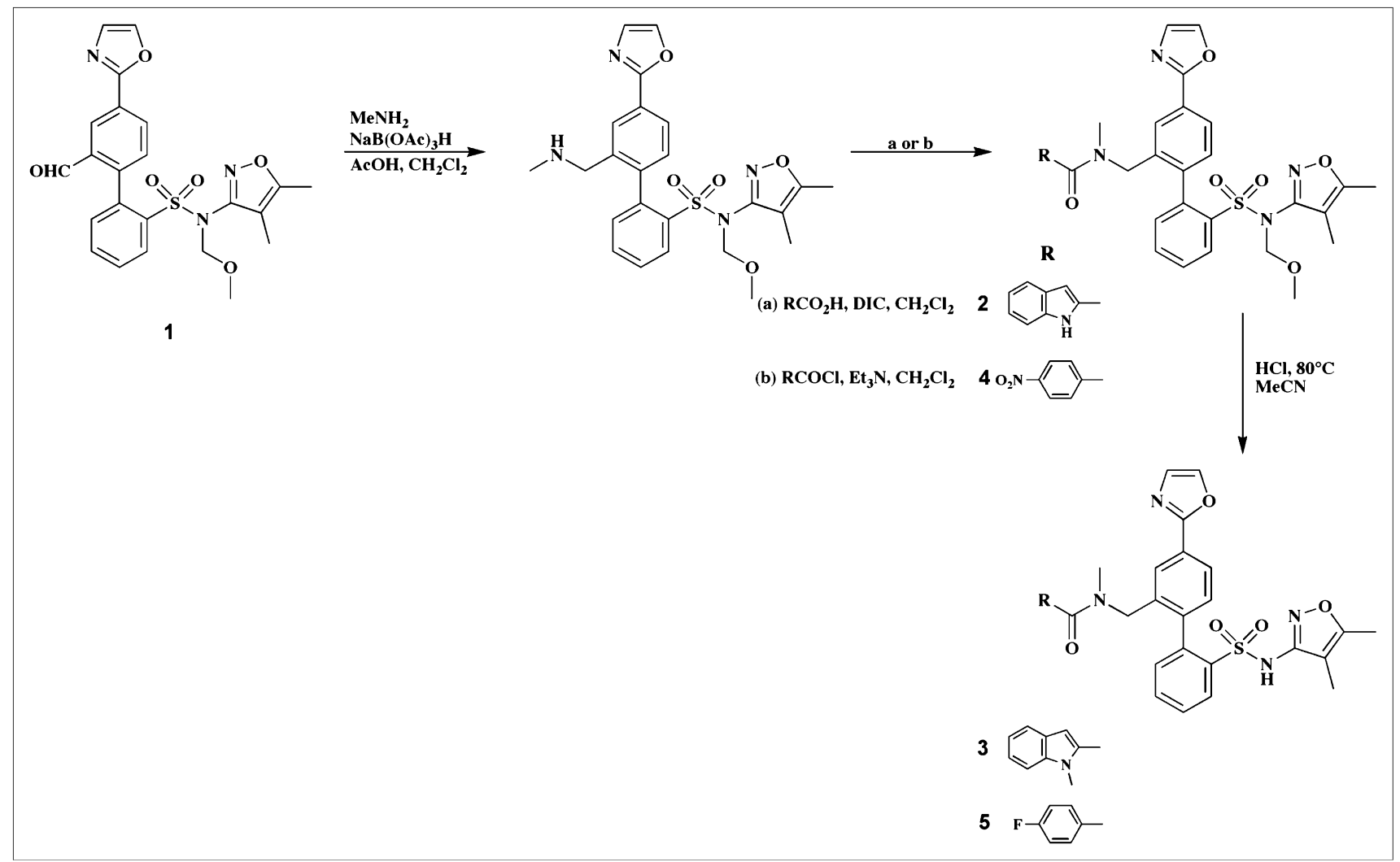

SCHEME 1. Synthesis of precursors 2 and 4 and authentic standards of BMS-5p 3 and FBzBMS 5.

$80^{\circ} \mathrm{C}$ for $8 \mathrm{~min}$. Increasing the hydrolysis temperature will probably improve the yield of the final product. Nevertheless, sufficient amounts of ${ }^{11} \mathrm{C}-\mathrm{BMS}-5 \mathrm{p} 3$ can be made to conduct in vivo PET studies. ${ }^{18} \mathrm{~F}-\mathrm{FBzBMS} 5$ was synthesized by nucleophilic displacement reaction using a protected para-nitro precursor 4 . The ${ }^{18} \mathrm{~F}$ synthesis is shown in Scheme 3. Unlike the ${ }^{11} \mathrm{C}$ synthesis, deprotection of the ${ }^{18} \mathrm{~F}$ intermediate was spontaneous under the radiofluorination conditions. No separate deprotection step was necessary. The use of larger quantities of precursor improved the radiochemical yield. This indicates a competition between ${ }^{18}$ F-fluoride incorporation and deprotection.

In mice, both radioligands showed high uptake in the liver, lungs, and heart. Radioactivity in the liver washed out over time, and uptake in the lungs and heart remained relatively stable. This uptake corresponds to the known density of endothelin receptors as measured in rats (15). Despite its lower lipophilicity, ${ }^{18} \mathrm{~F}-\mathrm{FBzBMS} 5$ showed higher liver uptake than did ${ }^{11} \mathrm{C}-\mathrm{BMS}-5 \mathrm{p} \mathbf{3}$, even at later time points. Low bone uptake, however, indicates that metabolic defluorination does not occur to any great extent. In fact, both radioligands exhibited relatively low rates of metabolism in mice. Although the calculated $\log P$ values for both BMS-5p 3 and FBzBMS 5 were in a range of 3.33.8 , there was no significant uptake in the brain because the sulfonamide moiety itself is polar. These ligands may also be substrates for the p-glycoprotein pump. High specific binding in the lungs, kidneys, and heart also agrees with the known density of endothelin receptors in these organs as measured in rats (15).

PET of the heart in a baboon has demonstrated the utility of both ${ }^{11} \mathrm{C}-\mathrm{BMS}-5 \mathrm{p} 3$ and ${ }^{18} \mathrm{~F}-\mathrm{FBzBMS} 5$ for delineating

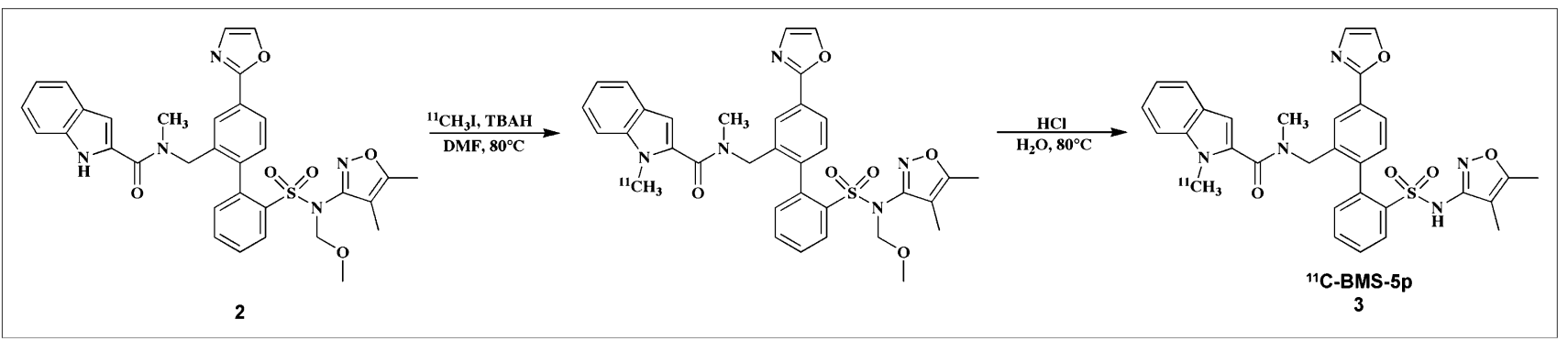

SCHEME 2. Radiosynthesis of ${ }^{11} \mathrm{C}-\mathrm{BMS}-5 \mathrm{p} 3$. 


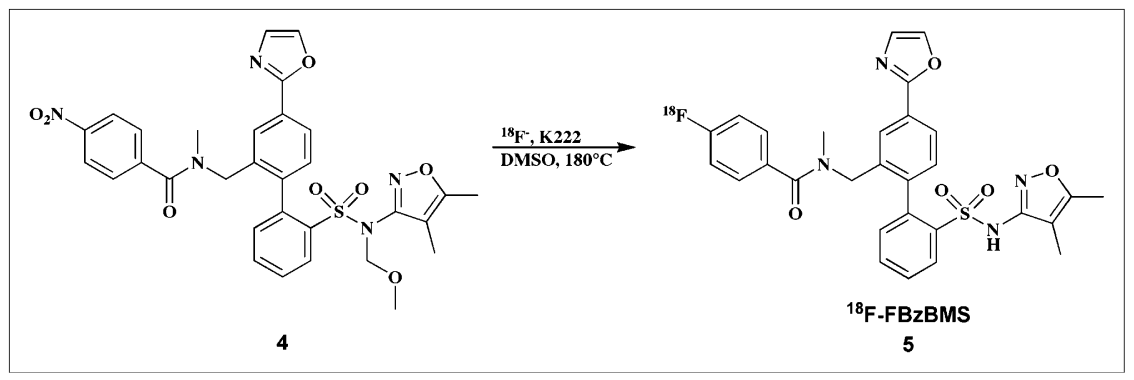

the ETA receptor in vivo. ${ }^{18} \mathrm{~F}-\mathrm{FBzBMS} 5$ gave a betterquality baseline image at later time points because of the longer half-life of ${ }^{18} \mathrm{~F}$. Also, ordered-subset expectation maximization reconstruction gave better image quality than did filtered backprojection. Although ${ }^{11} \mathrm{C}-\mathrm{BMS}-5 \mathrm{p} 3$ reached equilibrium earlier, both radioligands showed $85 \%$ specific binding at $85 \mathrm{~min}$ after injection. The metabolic profiles of both radioligands were also similar, with only $37 \%$ metabolized at $90 \mathrm{~min}$.

\section{CONCLUSION}

Both ${ }^{11} \mathrm{C}-\mathrm{BMS}-5 \mathrm{p} 3$ and ${ }^{18} \mathrm{~F}-\mathrm{FBzBMS} 5$ bind selectively to the ETA receptor in vivo. Further development of these radioligands for imaging the ETA receptor in humans is warranted.

\section{ACKNOWLEDGMENTS}

We thank Yan Xiang for helping with the in vitro assay, Daniel Holt and Robert Smoot for their assistance with the radiosyntheses, Paige Finley for performing the mouse dissections and baboon preparation, and Karen Edmonds for acquiring the baboon PET images. This work was supported by National Institutes of Health grants CA115532, DK50183, CA092871, and CA103175. ${ }^{125}$ I-endothelin-1 was kindly provided through a material transfer agreement with Dr. Robert C. Speth of the University of Mississippi.

\section{REFERENCES}

1. Yanagisawa M, Kurihara H, Kimura S, et al. A novel potent vasoconstrictor peptide produced by vascular endothelial cells. Nature. 1988;332:411-415.

2. Inoue A, Yanagisawa M, Kimura S, et al. The human endothelin family: three structurally and pharmacologically distinct isopeptides predicted by three separate genes. Proc Natl Acad Sci USA. 1989;86:2863-2867.

3. Wu-Wong JR, Opgenorth TJ. The roles of endothelins in proliferation, apoptosis, and angiogenesis. In: Warner TD, ed. Endothelin and Its Inhibitors. Berlin, Germany: Springer-Verlag; 2001;152:299-322.

4. Rubanyi GM, Polokoff MA. Endothelins: molecular biology, biochemistry, pharmacology, physiology, and pathophysiology. Pharmacol Rev. 1994;46:325-415.

5. Arai H, Hori S, Aramori I, Ohkubo H, Nakanishi S. Cloning and expression of a cDNA encoding an endothelin receptor. Nature. 1990;348:730-732.

6. Sakurai T, Yanagisawa M, Takuwa Y, et al. Cloning of a cDNA encoding a nonisopeptide-selective subtype of the endothelin receptor. Nature. 1990;348: 732-735.

7. Luscher TF, Barton M. Endothelins and endothelin receptor antagonists: therapeutic considerations for a novel class of cardiovascular drugs. Circulation. 2000;102:2434-2440.

8. Moreau P, Dao HH. An update on the status of endothelin receptor antagonists for hypertension. Expert Opin Investig Drugs. 2001;10:1937-1946.
9. Seed A, Love MP, McMurray JJ. Clinical experience with endothelin receptor antagonists in chronic heart failure. Heart Fail Rev. 2001;6:317-323.

10. Galie N, Manes A, Branzi A. The endothelin system in pulmonary arterial hypertension. Cardiovasc Res. 2004;61:227-237.

11. Davenport AP, Maguire JJ. Endothelin. Handb Exp Pharmacol. 2006;176(pt 1):295-329.

12. Bagnato A, Tecce R, Di Castro V, Catt KJ. Activation of mitogenic signaling by endothelin 1 in ovarian carcinoma cells. Cancer Res. 1997;57:1306-1311.

13. Kurbel S, Kurbel B, Kovacic D, et al. Endothelin-secreting tumors and the idea of the pseudoectopic hormone section in tumors. Med Hypotheses. 1999;52: 329-333.

14. Brennan PA, Zaki GA. Angiogenesis in cancer: the role of endothelin-1. Ann $R$ Coll Surg Engl. 2000;82:363-364.

15. Gibson RE, Fioravanti C, Francis B, Burns HD. Radioiodinated endothelin-1: a radiotracer for imaging endothelin receptor distribution and occupancy. Nucl Med Biol. 1999;26:193-199.

16. Johnström P, Harris NG, Fryer TD, et al. $\left[{ }^{18} \mathrm{~F}\right]$ endothelin-1, a positron emission tomography (PET) radioligand for the endothelin receptor system: radiosynthesis and in vivo imaging using microPET. Clin Sci. 2002;103(suppl 48):4S-8S.

17. Ravert HT, Mathews WB, Hamill TG, Burns HD, Dannals RF. Radiosynthesis of a potent endothelin receptor antagonist: $\left[{ }^{11} \mathrm{C}\right] \mathrm{L}-753,037$. J Labelled Comp Radiopharm. 2000;43:1205-1210.

18. Aleksic S, Szabo Z, Scheffel U, et al. In vivo labeling of endothelin receptors with $\left[{ }^{11} \mathrm{C}\right] \mathrm{L}-753,037$ : studies in mice and a dog. J Nucl Med. 2001;42:12741280 .

19. Johnström P, Aigbirhio FI, Clark JC, Downey SP, Pickard JD, Davenport AP. Syntheses of the first endothelin-A- and -B-selective radioligands for positron emission tomography. J Cardiovasc Pharmacol. 2000;36(5 suppl 1):S58-S60.

20. Johnström $P$, Rudd $\mathrm{JH}$, Richards $\mathrm{HK}$, et al. Imaging endothelin $\mathrm{ET}_{\mathrm{B}}$ receptors using $\left[{ }^{18} \mathrm{~F}\right]-\mathrm{BQ} 3020$ : in vitro characterization and positron emission tomography (microPET). Exp Biol Med. 2006;231:736-740.

21. Johnström P, Fryer TD, Richards HK, et al. In vivo imaging of cardiovascular endothelin receptors using the novel radiolabelled antagonist $\left[{ }^{18} \mathrm{~F}\right]-\mathrm{SB} 209670$ and positron emission tomography (microPET). J Cardiovasc Pharmacol. 2004;44(suppl):S34-S38.

22. Mathews WB, Zober TG, Ravert HT, et al. Synthesis and in vivo evaluation of a PET radioligand for imaging the endothelin-A receptor. Nucl Med Biol. 2006;33:15-19.

23. Hoeltke C, Wagner S, Breyholz H-J, et al. Development, synthesis and in vitro evaluation of novel ET-A receptor PET-radioligands based on PD 156707 [abstract]. J Labelled Comp Radiopharm. 2007;50:S345.

24. Murugesan N, Gu Z, Spergel S, et al. Biphenylsulfonamide endothelin receptor antagonists. 4. Discovery of $N$-[[2-[[(4,5-dimethyl-3-isoxazolyl)amino]sulfonyl]4-(2-oxazolyl)[1,1-biphenyl]-2-yl]methyl]- $N, 3,3$-trimethylbutanamide (BMS-207940), a highly potent and orally active ETA selective antagonist. J Med Chem. 2003; 46:125-137.

25. Halfman CJ. Concentrations of binding protein and labeled analyte that are appropriate for measuring at any analyte concentration range in radioimmunoassays. Methods Enzymol. 1981;74(pt C):481-497.

26. Coleman TF, Li Y. On the convergence of reflective Newton methods for largescale nonlinear minimization subject to bounds. Math Program Ser A. 1994; 67:189-224.

27. Hilton J, Yokoi F, Dannals RF, Ravert HT, Szabo Z, Wong DF. Columnswitching HPLC for the analysis of plasma in PET imaging studies. Nucl Med Biol. 2000;27:627-630.

28. Szabo Z, Xia J, Mathews WB. Radiopharmaceuticals for renal positron emission tomography imaging. Semin Nucl Med. 2008;38:20-31.

29. Zolk O, Quattek J, Sitzler G, et al. Expression of endothelin-1, endothelinconverting enzyme, and endothelin receptors in chronic heart failure. Circulation. 1999;99:2118-2123. 